\title{
THE ROLE OF PARLIAMENTARY CONTROL ON DEMOCRATIC REFORMS
}

\author{
Alisher Ollamov, \\ A doctoral candidate at the Academy of Public Administration under \\ the President of the Republic of Uzbekistan \\ Crossref \\ http://dx.doi.org/10.26739/2433-202x

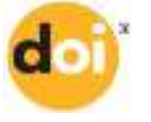 \\ Issue DOI http:/ / dx.doi.org/10.26739/2433-202x-2017-12-12 \\ Article DOI http:/ /dx.doi.org/10.26739/2433-202x-2017-12-12-7
}

\section{Abstract}

The article describes the powers of the Senate of the Oliy Majlis of the Republic of Uzbekistan for control. Also, It was analyzed legislative acts on the control of the Parliament of the Republic of Uzbekistan over executive bodies.

Keywords: Senate, parliamentary control, government, law, parliamentary investigation.

As a result of the wide-ranging democratic reforms being implemented in the country, the powers of the parliament have expanded and its role in the governance is growing. The Senate (upper chamber) of the Oliy Majlis of the Republic of Uzbekistan is a chamber of territorial representation and consists of one hundred members of the Senate. Members of the Senate (senators) shall be elected by secret ballot from the deputies of the Jokargy Kenes of the Republic of Karakalpakstan, deputies of representative bodies of the state power of the provincial, districts and cities of the Republic of Karakalpakstan, provinces and The city of Tashkent equals to six [1].

For example in USA, each Senator was classified by political party, gender, state, and the US geographic region of the state they represented (i.e., Midwest, Northeast, South, West; defined by the US Census Bureau). Political party was our primary independent variable and gender, state, geographic region, and voting year were covariates [2].

The guarantees for the unimpeded and effective implementation of the senator's rights and obligations are regulated by the Law of the Republic of Alisher Ollamov 
Uzbekistan "On the Status of a Deputy of the Legislative Chamber and a Member of the Senate of the Oliy Majlis of the Republic of Uzbekistan", other laws [3].

The Senate annually records at its session a report on the activities of the the authorized person of the Oliy Majlis for Human Rights (Ombudsman). The Senate shall hear and discuss the report of the Accounting Chamber of the Republic of Uzbekistan at its session every year after the decision of the Legislative Chamber on the matter. Resolutions of the Senate on the authorized person of the Oliy Majlis for Human Rights (Ombudsman) and the Accounting Chamber of the Republic of Uzbekistan shall be forwarded to the Legislative Chamber within ten days from the date of their adoption. In accordance with the procedure established by the legislation, the annual reports submitted by the General Prosecutor of the Republic of Uzbekistan, the Chairman of the State Committee for the Protection of Nature of the Republic of Uzbekistan, Chairman of the Board of the Central Bank of the Republic of Uzbekistan to the Senate. Senate committees, as well as senators, may request documents, expert conclusions, statistical data and other information from government agencies and other organizations and officials. Information required by the Senate committees or senators must be submitted no later than ten days from the date of application by the relevant state body, other organization or official. The heads of bodies of state power and administration of the commissions, hearings of the decisions of the committees on the decisions of the committees are conducted in accordance with the committees' work plans.

The Senate, as well as the senators, has the right to send parliamentary inquiries to officials of state power and governance bodies with a request to provide substantiated explanations or express their views on matters within their authority. Officials of state power and administration shall submit an answer to the parliamentary inquiry. The parliamentary inquiry submitted to the Chairperson of the Supreme Court of the Republic of Uzbekistan, the Chairman of the Supreme Economic Court, the Prosecutor General, the heads of the inquiry and investigation bodies may not be relevant to the particular cases and materials in their proceedings. The information can be discussed at the session of the Senate. The Senate decides on the results of the discussion.

Also, the Law "On Parliamentary control" [4] contributes to further strengthening the role of the Oliy Majlis of the Republic of Uzbekistan.

The adoption of this law was based on the concepts of the rule of law in the society, the concepts of strengthening the role of legislative power, as well as amendments to the Constitution in recent years.

\section{Alisher Ollamov}


Another important aspect of the adoption of the "Parliamentary Oversight Act" was that the control of the implementation of the laws on the ground, as well as the in-depth and systematic study, allowed timely identification of problems in the law enforcement practice.

On the basis of the law, a new institute called "parliamentary investigation" was launched. It has been established that parliamentary inquiries can be conducted by a joint resolution of the Oliy Majlis for the study of certain facts or events that may affect the fundamental interests of society and the state, which may have a negative impact on its sustainable development. With this mechanism, the parliament has the right to express its attitude to important processes in society.

This will have a positive impact not only on the rule of law and the rule of law in our society, but also on improving the quality and the quality of life of our citizens. The law promotes the rise of reforms in the country to a new level in the process of democratizing the state and society building, the comprehensive development and strengthening of parliamentarism.

It should be noted that the law incorporates national experience in the field of parliamentary oversight, advanced practice of foreign democratic countries and innovations in this area. Among the new forms of parliamentary control set out in this law are the methods used in the parliamentary practice such as monitoring the adoption of legislation and the parliamentary oversight of the enforcement of laws.

The Legislative Chamber and the Senate of the Oliy Majlis, committees, commissions, factions of political parties in the Legislative Chamber, deputy groups, members of the Senate, and the authorized person of the Oliy Majlis for Human Rights (Ombudsman) [5].

Article 10 lists the following norms that are of paramount importance to parliament: the Legislative Chamber, the Senate may, at times where necessary, hear the members' information on matters related to their activities at their meetings. The issue of hearing the information of government members on their activities is considered by the Legislative Chamber on the initiative of the factions and the deputy groups, and by the Senate at the initiative of the committees. Upon hearing the information of the members of the Government, the Legislative Chamber and the Senate will take a decision to make proposals for increasing the effectiveness of government members and their performance.

Moreover, Article 25 of the Law sets out the rules for the conduct of the parliamentary hearings' results by holding open sessions of the Legislative Chamber, the Senate and their bodies, and publishing it on the official web-

\section{Alisher Ollamov}


sites of the Legislative Chamber and Senate [6]. This principle also reflects the transparency of parliamentary activity.

The law outlines the goals, objectives, principles, modern forms and methods of parliamentary control, its subjects and objects. Its main purpose is to regulate relations in the field of parliamentary oversight and implementation, to improve the interaction of legislative and executive bodies, as well as to create additional mechanisms for enhancing the accountability of public administration bodies to the parliament. In a word, this law, together with the legislative activity of the parliament, will further enhance the effectiveness of the control and analytical work carried out by members of parliament.

In line with the path of development of Uzbekistan recognized by the world community, consistent and gradual implementation of large-scale work on strengthening the role, powers and control functions of the parliament, which has been an important component of the system of checks and balances between the government branches over the past years.

The concept of intensifying the democratic reforms and forming civil society in the country was a legitimate and logical continuation of the reform of the system of democratization, interconnection and equilibrium of the state power. As noted above, amendments to the Constitution and other legislative acts of recent years have served to facilitate the optimization of the main subjects of state power, including the Oliy Majlis and the Government, in the field of public administration and the development of the system of mutual checks and balances between the authorities.

Particularly, Article 78 of the Constitution, with the aim of expanding and strengthening the oversight powers of the legislature, has been complemented by the provisions governing the constitutional strengthening of the powers of the parliament to exercise parliamentary control [7]. This, in turn, plays an important role in strengthening the constitutional foundations of the system of mutual checks and balances, further expansion and development of the parliamentary control body.

The Law "On parliamentary control" provides for control of the activities of the Senate's Prosecutor's Office in order to improve parliamentary control of prosecutorial offices, to enhance the effectiveness of their work on ensuring the rule of law and legitimacy in the country, protection of the rights and freedoms of citizens, the structure of the commission was strengthened at the legislative level.

Improving the legal framework of parliamentary control, enhancing the role of the parliament in ensuring the implementation of laws and state Alisher Ollamov 
programs, and enhancing the effectiveness of the oversight activities of the Oliy Majlis [8].

In summary, the Oliy Majlis is a deputy of the Legislative Chamber or a member of the Senate should exercise the powers vested thereto effectively for the benefit of the people and the country. Indeed, as the President has emphasized, our people should be aware of the changes in life, and must be aware that they have a real representation in the system of government. Otherwise, all our work and actions will be lost. 


\section{REFERENCE}

1. Constitution of the Republic of Uzbekistan Part five. Organization of state authority. Chapter XVIII. Oliy Majlis of the Republic of Uzbekistan. Article 76. http://constitution.uz/en/clause/index

2. J.Purtle, N.D.Goldstein, E.Edson, A.Hand. Who votes for public health? U.S. senator characteristics associated with voting in concordance with public health policy recommendations (1998-2013), SSM - Population Health, Volume 3 ,

December 2017, pp.136-140. https://www.sciencedirect.com/science/article/pii/S2352827316300714

3. Collection of the legislation of the Republic of Uzbekistan, 2017, N 37, art. 978

4. Collection of the legislation of the Republic of Uzbekistan, 2017, N 24, article 487

5. Collection of the legislation of the Republic of Uzbekistan, 2017, N 24, article 487

6. Collection of the legislation of the Republic of Uzbekistan, 2017, No. 24, article 487

7. Constitution of the Republic of Uzbekistan-T .: Uzbekistan. 2014

8. http://senat.uz/en/news/2018/article/23-01-2.html 